\title{
David Oliver: Why I'm changing my mind about resuscitation
}

\section{David Oliver consultant in geriatrics and acute general medicine}

Berkshire

I've written before about planning end of life care, ${ }^{1}$ pragmatism in decisions regarding "do not attempt cardiopulmonary resuscitation" (DNACPR), and possible dissonance between legal rulings and clinicians' daily realities. ${ }^{2}$ I've called for more measured media reporting and said that dying people need protection from undignified, distressing medicalised intervention. ${ }^{13}$

My columns and others on DNACPR have elicited many responses, ${ }^{45}$ notably from Kate Masters, ${ }^{67}$ whose father's action led to the Tracey judgment. Kate has been contacted by many families with similar stories.

A memorable letter described resuscitation as "the routine, institutionalised electrocution and torture of the dying" (BMA Newsletter, June 2016). Some people understandably prefer the term "allow natural death" to "DNACPR."

I've been contacted by doctors sharply distinguishing between resuscitation in people with life limiting conditions and in fit people with sudden unexpected illness or injury. I've read preliminary research from Scotland finding that many older inpatients were perfectly willing and able to discuss limits of treatment. $^{9}$

I've reflected on analogies between DNACPR and other medical interventions-despite its special status as an immediate lifesaving treatment that can be initiated anywhere and by anyone.

For hospital inpatients and care home residents, we should do all we can to avoid CPR without patient consent or best interest discussions with families

For registered practitioners, common law precedent already protects us in acting without patient consent in life threatening situations when time won't allow otherwise. ${ }^{10}$ But, for most patients entering hospital, the possibility of resuscitation could reasonably be anticipated and planned for.

Consent law means that clinicians must disclose a reasonable degree of information on the risks and benefits of medical interventions. ${ }^{11}$ Compressions, intubation, cannulation, powerful drugs, and electrical shocks are surely such interventions.
Informed consent for CPR would also need discussion of success rates, injuries, anoxic brain damage, intensive care admission, and ventilation-and the patient's own goals if he or she survives.

I'm coming gradually to a view that, for hospital inpatients and care home residents, we should do all we can to avoid CPR without patient consent or best interest discussions with families. Documenting CPR status for all patients would also remove the ambiguity when a crash team arrives at the bedside and finds no form. Is the decision to attempt resuscitation deliberate or an oversight?

Doctors are under no obligation to offer CPR on demand if it would be futile or harmful, but documenting the decision for every patient could ensure that it's been explained and that no patients or families are taken by surprise.

I don't underestimate the difficulties in realising this. Competing pressures and priorities may cause perfunctory, rushed, poorly understood, or distressing discussions and take valuable time from other work. But I do welcome further debate, including any sparked by related articles in this issue of The BMJ, and the Resuscitation Council's ongoing "Emergency Care and Treatment Plan" (RESPECT). ${ }^{12}$

Competing interests: See www.bmj.com/about-bmj/freelancecontributors/david-oliver.

Provenance and peer review: Commissioned; not externally peer reviewed.

Oliver D. What to do about end of life scare stories. BMJ 2015;356:h4846. doi:10.1136/ bmj.h4846 pmid:26362213.

2 Oliver D. Resuscitation orders and reality. BMJ 2016;356:11494. doi:10.1136/bmj. i1494 pmid:26980294.

3 Oliver D. Fear mongering headlines can harm end of life care. Health Serv J 2015 Apr 30. www.hsj.co.uk/comment/fear-mongering-headlines-can-harm-end-of-life-care/5084585. fullarticle.

4 Etheridge Z, Gatland E. When and how to discuss "do not resuscitate" decisions with patients. BMJ 2015;356:h2640. doi:10.1136/bmj.h2640 pmid:25994629.

5 Sokol DK. Cautionary tales about DNACPR. BMJ 2016;356:i26. doi:10.1136/bmj.i26 pmid: 26733107.

6 Masters K. Rapid response to David Oliver. Resuscitation orders and reality. BMJ2016. www.bmj.com/content/352/bmj.i1494/rapid-responses. 
7 Masters K. My mum's care means that decisions not to resuscitate must now be discussed with patients. BMJ 2017;356:j1084. doi:10.1136/bmj.j1084.

8 NHS End of Life Care Programme. DNACPR decisions: who decides and how? Sep 2012 www.Iwdwtraining.uk/wp-content/uploads/2012/09/DNACPR-decisions-who-decides-andhow-Sept-2012.pdf.

9 Smith J, Keir S. Cardiopulmonary resuscitation discussions in the elderly: do not avoid the conversation. Abstract British Geriatrics Society Spring Meeting, Liverpool. May 2016. www.bgs.org.uk/pdf_cms/admin_archive/2016 spring_abstracts.pdf (p 47).

10 Brazier M, Cave E. Medicine, patients and the law (revised and updated 5th ed): consent . Penguin, 2011
11 Poole N. Learned Friend blog: patient autonomy triumphs over medical paternalism. 11 Mar 2015. At http://nigelpooleqc.blogspot.co.uk/2015/03/patient-autonomy-triumphs-overmedical.html.

12 Resuscitation Council (UK). ReSPECT: progress update: June 2016. https://www.resus. org.uk/consultations/respect/.

Published by the BMJ Publishing Group Limited. For permission to use (where not already granted under a licence) please go to http://group.bmj.com/group/rights-licensing/ permissions 